\title{
Front Matter: Volume 8162
}

, "Front Matter: Volume 8162," Proc. SPIE 8162, Free-Space and Atmospheric Laser Communications XI, 816201 (26 September 2011); doi:

10.1117/12.913670

SPIE Event: SPIE Optical Engineering + Applications, 2011, San Diego, California, United States 


\title{
PROCEEDINGS OF SPIE
}

\section{Free-Space and Atmospheric Laser Communications XI}

\author{
Arun K. Majumdar \\ Christopher C. Davis \\ Editors
}

24-25 August 2011

San Diego, California, United States

Sponsored and Published by

SPIE 
The papers included in this volume were part of the technical conference cited on the cover and title page. Papers were selected and subject to review by the editors and conference program committee. Some conference presentations may not be available for publication. The papers published in these proceedings reflect the work and thoughts of the authors and are published herein as submitted. The publisher is not responsible for the validity of the information or for any outcomes resulting from reliance thereon.

Please use the following format to cite material from this book:

Author(s), "Title of Paper," in Free-Space and Atmospheric Laser Communications XI, edited by Arun K. Majumdar, Christopher C. Davis, Proceedings of SPIE Vol. 8162 (SPIE, Bellingham, WA, 201 1) Article CID Number.

ISSN 0277-786X

ISBN 9780819487728

Published by

SPIE

P.O. Box 10, Bellingham, Washington 98227-0010 USA

Telephone +1 3606763290 (Pacific Time) · Fax +1 3606471445

SPIE.org

Copyright (C) 2011, Society of Photo-Optical Instrumentation Engineers

Copying of material in this book for internal or personal use, or for the internal or personal use of specific clients, beyond the fair use provisions granted by the U.S. Copyright Law is authorized by SPIE subject to payment of copying fees. The Transactional Reporting Service base fee for this volume is $\$ 18.00$ per article (or portion thereof), which should be paid directly to the Copyright Clearance Center (CCC), 222 Rosewood Drive, Danvers, MA 01923. Payment may also be made electronically through CCC Online at copyright.com. Other copying for republication, resale, advertising or promotion, or any form of systematic or multiple reproduction of any material in this book is prohibited except with permission in writing from the publisher. The CCC fee code is 0277-786X/11/ \$18.00.

Printed in the United States of America.

Publication of record for individual papers is online in the SPIE Digital Library.

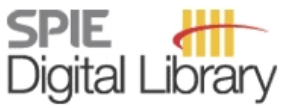

SPIEDigitalLibrary.org

Paper Numbering: Proceedings of SPIE follow an e-First publication model, with papers published first online and then in print and on CD-ROM. Papers are published as they are submitted and meet publication criteria. A unique, consistent, permanent citation identifier (CID) number is assigned to each article at the time of the first publication. Utilization of CIDs allows articles to be fully citable as soon as they are published online, and connects the same identifier to all online, print, and electronic versions of the publication. SPIE uses a six-digit CID article numbering system in which:

- The first four digits correspond to the SPIE volume number.

- The last two digits indicate publication order within the volume using a Base 36 numbering system employing both numerals and letters. These two-number sets start with $00,01,02,03,04$, $05,06,07,08,09,0 A, 0 B \ldots 0 Z$, followed by 10-1Z, 20-2Z, etc.

The CID number appears on each page of the manuscript. The complete citation is used on the first page, and an abbreviated version on subsequent pages. Numbers in the index correspond to the last two digits of the six-digit CID number. 


\section{Contents}

vii Conference Committee

\section{SESSION 1 SATELLITE AND SPACE FREE-SPACE OPTICAL COMMUNICATIONS}

816202 Lunar optical wireless communication and navigation network for robotic and human exploration (Invited Paper) [8162-01]

S. Arnon, Ben-Gurion Univ. of the Negev (Israel)

816203 Lightweight, mobile free-space optical communications in disaster scenarios for transmission of Earth observation data: feasibility study [8162-02]

O. Topcu, Technische Univ. Ilmenau (Germany); H. Henniger, Deutsches Zentrum für Luftund Raumfahrt e.V. (Germany); L. Grobe, M. Haardt, A. Mitschele-Thiel, T. Simon, Technische Univ. IImenau (Germany)

816204 Improved climatological characterization of optical turbulence for free-space optical communications [8162-03]

B. D. Felton, R. J. Alliss, Northrop Grumman Corp. (United States)

\section{SESSION 2 JOINT SESSION WITH CONFERENCE 8161}

816205 Twelve mortal sins of the turbulence propagation science (Invited Paper) [8162-05]

M. Charnotskii, Zel Technologies, LLC (United States) and National Oceanic and

Atmospheric Administration (United States)

816207 Experimental analysis of orbital angular momentum-carrying beams in furbulence [8162-07]

J. A. Anguita, J. Herreros, Univ. de Los Andes (Chile)

\section{SESSION 3 SCINTILLATION EFFECTS ON FSO LINKS}

816208 Optical scintillation measurements in a desert environment I: direct link ranges of 2 to $24 \mathbf{~ k m}$ [8162-08]

R. Mahon, C. I. Moore, M. S. Ferraro, W. S. Rabinovich, M. R. Suite, U.S. Naval Research Lab. (United States)

816209 Optical scintillation measurements in a desert environment II: retroreflector links [8162-09] W. S. Rabinovich, R. Mahon, C. I. Moore, M. S. Ferraro, M. R. Suite, H. R. Burris, Jr., L. M. Thomas, U.S. Naval Research Lab. (United States)

$81620 \mathrm{~A}$ Optical scintillation measurements in a desert environment III: high-speed imaging of scintillation patterns and their application to aperture averaging [8162-10] R. Mahon, C. I. Moore, M. S. Ferraro, W. S. Rabinovich, M. R. Suite, U.S. Naval Research Lab. (United States) 
8162 OB Optical scintillation measurements in a desert environment IV: simulated effects of scintillation on communications links [8162-11]

M. Suite, W. S. Rabinovich, R. Mahon, C. Moore, M. Ferraro, H. R. Burris, Jr., L. M. Thomas, U.S.

Naval Research Lab. (United States)

\section{SESSION 4 NOVEL DEVICES AND APPLICATIONS}

8162 OD InGaAs avalanche photodiode arrays for simultaneous communications and tracking [8162-13]

M. S. Ferraro, R. Mahon, W. S. Rabinovich, U.S. Naval Research Lab. (United States);

W. T. Freeman, Smart Logic, Inc. (United States); J. L. Murphy, P. G. Goetz, H. R. Burris,

C. I. Moore, L. M. Thomas, U.S. Naval Research Lab. (United States); W. R. Clark, W. D. Waters, Optogration, Inc. (United States)

8162 OE Design and implementation of pan-tilt FSO transceiver gimbals for real-time compensation of platform disturbances using a secondary control network [8162-14]

J. Rzasa, S. D. Milner, C. C. Davis, Univ. of Maryland, College Park (United States)

\section{SESSION 5 CODING FOR FSO COMMUNICATIONS}

$81620 \mathrm{O}$ On the LDPC-coded OAM modulation for communication over atmospheric turbulence channels [8162-16]

I. B. Djordjevic, The Univ. of Arizona (United States); J. Anguita, Univ. de Los Andes (Chile);

B. Vasic, The Univ. of Arizona (United States)

$8162 \mathrm{OH} \quad$ Performance analysis of optical wireless communications on long-range links [8162-17]

B. Epple, Codex GmbH \& Co. KG (Germany)

$81620 \mathrm{~J}$ Chaotic bandgaps in hybrid acousto-optic feedback and their implications [8162-19] M. R. Chatterjee, M. A. Al-Saedi, Univ. of Dayton (United States)

\section{SESSION $6 \quad$ UV AND VISIBLE FSO FOR INDOOR AND OUTDOOR COMMUNICATIONS}

8162 OK A 280Mbit/s infrared optical wireless communications system [8162-20]

D. O'Brien, Univ. of Oxford (United Kingdom); R. Turnbull, Swindon Silicon Systems (United Kingdom); H. Le Minh, Northumbria Univ. (United Kingdom); G. Faulkner, Univ. of Oxford (United Kingdom); M. Wolf, L. Grobe, J. Li, Technische Univ. Ilmenau (Germany); O. Bouchet, France Telecom R\&D (France); E. Gueutier, Apside Groupe (France)

8162 OL Broadcast of four HD videos with LED ceiling lighting: optical-wireless MAC [8162-21] O. Bouchet, P. Porcon, France Telecom R\&D (France); E. Gueutier, Apside Groupe (France)

8162 ON FSO and radio link attenuation: meteorological models verified by experiment [8162-23] V. Brazda, O. Fiser, J. Svoboda, Institute of Atmospheric Physics of the ASCR, v.v.i. (Czech Republic) 
816200 An aperture-matched phase-compensated differential phase shift keying receiver with a $90^{\circ}$ hybrid [8162-24]

Z. Luan, Y. Zhou, Y. Zhi, E. Dai, J. Sun, L. Liu, Shanghai Institute of Optics and Fine Mechanics (China)

8162 OS Simple phase-shifting method in Jamin double-shearing interferometer for testing of diffraction-limited wavefront [8162-28]

L. Wang, L. Liu, Z. Luan, J. Sun, Y. Zhou, Shanghai Institute of Optics and Fine Mechanics (China)

8162 OT Influence of laser beam profiles on received power fluctuation [8162-29]

L. Dordova, J. Diblik, Brno Univ. of Technology (Czech Republic)

$81620 \mathrm{U}$ Acquisition strategy for the satellite laser communications under the laser terminal scanning errors situation [8162-30]

J. Sun, L. Liu, W. Lu, A. Yan, Y. Zhou, Shanghai Institute of Optics and Fine Mechanics (China)

$81620 \mathrm{~V}$ Influence of optical elements on the laser beam profile [8162-31]

O. Wilfert, J. Komrska, J. Poliak, Z. Kolka, Brno Univ. of Technology (Czech Republic)

8162 OW Power budget model for indoor wireless optical link [8162-32]

O. Wilfert, A. Prokes, J. Diblik, P. Hrbackova, Brno Univ. of Technology (Czech Republic)

8162 0X Decoding nonsystematic Reed-Solomon codes using the Berlekamp-Massey algorithm [8162-33]

T.-C. Lin, T.-K. Truong, I-Shou Univ. (Taiwan)

8162 OY Two-dimension image construction for range-resolved reflective tomography laser radar [8162-35]

Y. Yan, J. Sun, X. Jin, L. Liu, Shanghai Institute of Optics and Fine Mechanics (China)

$81620 Z$ Control analysis of acquirement and locking in inter-satellite laser communications [8162-04]

W. Lu, J. Sun, Y. Zhou, Y. Wu, A. Yan, E. Dai, Y. Zhi, L. Liu, Shanghai Institute of Optics and Fine Mechanics (China)

Author Index 
Downloaded From: https://www.spiedigitallibrary.org/conference-proceedings-of-spie on 25 Apr 2023

Terms of Use: https://www.spiedigitallibrary.org/terms-of-use 


\title{
Conference Committee
}

\author{
Program Track Chairs
}

Stephen M. Hammel, Space and Naval Warfare Systems Command (United States)

Alexander M. J. van Eijk, TNO Defence, Security and Safety

(Netherlands)

\section{Conference Chairs}

Arun K. Majumdar, Naval Air Warfare Center Weapons Division (United States)

Christopher C. Davis, University of Maryland, College Park (United States)

\section{Program Committee}

Larry C. Andrews, University of Central Florida (United States)

Jaime A. Anguita, Universidad de Los Andes (Chile)

Shlomi Arnon, Ben-Gurion University of the Negev (Israel)

Mikhail S. Belen'kii, Trex Enterprises Corporation (United States)

Don M. Boroson, MIT Lincoln Laboratory (United States)

Naresh Chand, BAE Systems (United States)

Bernhard Epple, DLR Standort Oberpfaffenhofen (Germany)

Charmaine Gilbreath, U.S. Naval Research Laboratory (United States)

Anjan K. Ghosh, The University of Oklahoma - Tulsa (United States)

Hennes Henniger, Deutsches Zentrum für Luft- und Raumfahrt e.V. (Germany)

Stuart D. Milner, University of Maryland, College Park (United States)

Dominic C. O'Brien, University of Oxford (United Kingdom)

Jacobus M. Oschmann, Jr., Ball Aerospace \& Technologies

Corporation (United States)

Ronald R. Parenti, MIT Lincoln Laboratory (United States)

William S. Rabinovich, U.S. Naval Research Laboratory (United States)

Larry B. Stotts, Defense Advanced Research Projects Agency (United States)

Otakar Wilfert, Brno University of Technology (Czech Republic)

Zhengyuan Xu, University of California, Riverside (United States) 
Session Chairs

1 Satellite and Space Free-Space Optical Communications

Arun K. Majumdar, Naval Air Warfare Ctr. Weapons Div. (United States)

Christopher C. Davis, University of Maryland, College Park (United States)

2 Joint Session with Conference 8161

Alexander M. J. van Eijk, TNO Defence, Security and Safety (Netherlands)

Christopher C. Davis, University of Maryland, College Park (United States)

3 Scintillation Effects on FSO Links

Jaime A. Anguita, Universidad de Los Andes (Chile)

$4 \quad$ Novel Devices and Applications

Shlomi Arnon, Ben-Gurion University of the Negev (Israel)

5 Coding for FSO Communications

Hennes Henniger, Deutsches Zentrum für Luft- und Raumfahrt e.V. (Germany)

$6 \quad$ UV and Visible FSO for Indoor and Outdoor Communications

William S. Rabinovich, U.S. Naval Research Laboratory (United States) 